African Crop Science Journal by African Crop Science Society is licensed under a Creative Commons Attribution 3.0 Uganda License. Based on a work at www.ajol.info/ and www.bioline.org.br/cs DOI: https://dx.doi.org/10.4314/acsj.v29i1.5

\title{
MORPHOLOGICAL CHARACTERISTICS AND GENETIC DIVERSITY OF ETHIOPIAN SESAME GENOTYPES
}

\author{
T. TESFAYE ${ }^{1,2}$, K. TESFAYE ${ }^{2}$, G. KENENI ${ }^{3}$ and T. ALEMU ${ }^{3}$ \\ ${ }^{1}$ Amhara Agricultural Research Institute, Gondar Research Center, P. O. Box 1337, Gondar, Ethiopia \\ ${ }^{2}$ Addis Ababa University, College of Natural Sciences, Department of Microbial, Cellular \\ and Molecular Biology, P. O. Box 1176, Addis Ababa, Ethiopia \\ ${ }^{3}$ Ethiopian Institute of Agricultural Research, Holeta Research Center, P. O. Box 2003, \\ Holeta, Ethiopia \\ Corresponding author: tesfaye.tewodros@yahoo.com
}

(Received 14 September 2020; accepted 4 January 2021)

\begin{abstract}
Sesame (Sesamum indicum L.) is produced worldwide, although more than $96 \%$ of the world sesame seed is produced in Africa and Asia. The objective of this study was to determine morphological properties and identify the genetic diversity of cultivated sesame genotypes grown in different parts of Ethiopia. Three hundred sesame genotypes collected from diverse ecologies of Ethiopia and introduced from different African and Asian countries, were used in this study. Genotypes showed wide variability for most morphological traits, except for plant growth type, leaf glands, anther filament colour, anther connective tip gland, and anthocyanin colouration of the capsule. Genetic divergence using Mahalanobis D2 statistics was computed, and the genotype lines were grouped into six different clusters. Clustering was not associated with the geographical distribution; instead genotypes were grouped mainly based on morphological differences. The lowest divergence was noticed between cluster I and V (10.06). Maximum inter-cluster distance was observed between clusters IV and VI (D2 $=342.56$, followed by clusters I and VI (D2 =217.9783), and III with IV (D2=190.8707). Maximum genetic recombination and variation in the subsequent generation, is expected from crosses that involve parents from the clusters characterised by maximum distances. Thus, maximum distances or varation could maximise opportunities for transgressive segregation, since unrelated genotypes would contribute unique desirable alleles at different loci.
\end{abstract}

Key Words: Inter-cluster distance, Mahalanobis D2 statistics, transgressive segregation

\section{RÉSUMÉ}

Le sésame (Sesamum indicum L.) est produit dans le monde entier, bien que plus de $96 \%$ de la graine de sésame mondiale soit produite en Afrique et en Asie. L'objectif de cette étude était de déterminer les propriétés morphologiques et d'identifier la diversité génétique des génotypes de sésame cultivés dans différentes régions d'Éthiopie. Trois cents génotypes de sésame collectés dans diverses écologies d'Éthiopie et introduits dans différents pays africains et asiatiques ont été utilisés dans cette étude. 
Les génotypes ont montré une grande variabilité pour la plupart des caractères morphologiques, à l'exception du type de croissance des plantes, des glandes foliaires, de la couleur du filament d'anthère, de la glande de l'extrémité conjonctive de l'anthère et de la coloration anthocyanique de la capsule. La divergence génétique à l'aide des statistiques de Mahalanobis D2 a été calculée, et les lignées génotypiques ont été regroupées en six groupes différents. Le regroupement n'était pas associé à la répartition géographique; au lieu de cela, les génotypes ont été regroupés principalement en fonction des différences morphologiques. La divergence la plus faible a été observée entre les grappes I et $\mathrm{V}$ $(10,06)$. La distance maximale d' inter-grappes a été observée entre les grappes IV et VI (D2 = 342,56, suivie des grappes I et VI $(D 2=217,9783)$ et III avec IV $(D 2=190,8707)$. La recombinaison génétique maximale et la variation dans la génération suivante est attendu de croisements qui impliquent des parents des grappes caractérisées par des distances maximales. Ainsi, les distances maximales ou la variation pourraient maximiser les possibilités de ségrégation transgressive, puisque des génotypes non apparentés apporteraient des allèles uniques souhaitables à différents locus.

Mots Clés: Distance inter-grappe, statistiques Mahalanobis D2, ségrégation transgressive

\section{INTRODUCTION}

Sesame (Sesamum indicum L.) is a major oil seed crop worldwide, with more than $96 \%$ of seed production accounted for by Africa and Asia (FAOSTAT, 2017). Sesame seeds are richly endowed with oil (44-57\%), protein (18$25 \%$ ) and carbohydrates (13-14\%) (Borchani, 2010). Cultivated sesame has been described as a self-pollinated species; however, varying degrees of natural crossing to the extent of 2 to $48 \%$ have been reported (Daniel and Parzies, 2011).

In Ethiopia, sesame accounts for about $44 \%$ of the total acreage and $34 \%$ of gross production of major oilseeds cultivated in the country. It grows in almost all regions of the country with altitudes less than $2000 \mathrm{~m}$ above sea level (Yebiyo, 1985; Adefris et al., 2011). Farm level national average productivity in Ethiopia is lower $\left(0.68 \mathrm{tha}^{-1}\right)$ (CSA 2019) than the potential yield of $2 \mathrm{t} \mathrm{ha}^{-1}$ (Mkamilo and Bedigian, 2007). Improved varieties released in Ethiopia reportedly yield 0.3 to $1.3 \mathrm{t} \mathrm{ha}^{-1}$ under rainfed, and 1 to $2.4 \mathrm{tha}^{-1}$ under irrigated conditions (Gebremichael, 2017).

Sesame is one of the major indigenous oilseeds, displaying considerable diversity in Ethiopia (IBC, 2012). Moreover genetic diversity in crop plants is essential to sustain high productivity (Rabbani et al., 2010). A large number of Ethiopian sesame germplasm, locally collected and introduced, are held in the gene bank and in breeders' stock. There have been efforts on the use of agromorphological characterisation, since the agromorphological marker has been a primary tool for estimating genetic differences among Ethiopian sesame genotypes (Desawi et al, 2014; Abate and Mekbib, 2015; Abate et al, 2015).

Genetic diversity with agro-morphological characterisation and eco-geographic distribution; and microcentres of the diversity have a number of limitations. Despite the huge amount of locally collected and introduced germplasm held in the Ethiopian gene bank, and in breeders' stock, sesame morphological characterisation has only been done on a limited number of genotypes. The objective of this study was to determine the level of morphological variation and to cluster the Ethiopian sesame genotypes of different origins into similarity groups and assess the extent and pattern of diversity of the genotypes.

\section{MATERIALS AND METHODS}

Materials used. A total of 300 sesame genotypes, comprising 225 local Ethiopian collections, including 16 released varieties and 75 exotic collections received from the Biodiversity Conservation Institute (IBC) of Ethiopia, and different federal and regional 
research centre of Ethiopia, were used in this study. The collections were mainly from different regions of Ethiopia, and different countries of Africa and Asia. The number of sesame genotypes used in this study and their countries of origin are listed in Table 1.

The genotypes were planted at the Metema trial site (120 39' N, 360 17' E) in the 2017/18 cropping season, and this was repeated in the 2018/19 cropping season at Metema and T/ Armacho trial (13088'N, 370 43'E) sites. Metema is located at 760 meters above sea level and receives $1030.2 \mathrm{~mm}$ of rainfall per annum and its soil is a Vertisol. T/Armacho is located at 1022 meters above sea level and receives $970.88 \mathrm{~mm}$ of rainfall per annum, also with a Vertisol.

The study was laid out in an alpha lattice design, with each plot consisting of two rows of $4 \mathrm{~m}$ length with a spacing of $40 \mathrm{~cm}$ between rows and $10 \mathrm{~cm}$ between plants. Up to $65 \mathrm{~kg}$ $\mathrm{ha}^{-1}$ of Urea, with two times split application, was applied manually based unpublished site specific recommendations. Thinning and hand weeding were carried out.

All quantitative (plant height, primary branch, secondary branch, length of basal leaf, width of basal leaf, length of middle leaf, width of middle leaf, length of top leaf, width of top leaf, petiole length of basal leaf, petiole length at middle (mid-level/mid-height) leaf, petiole length of top leaf, days to flower initiation, days to $50 \%$ flowering, number of capsules per plant, mean capsule length, mean capsule width, mean capsule thickness, seeds per capsule, 1000-seed weight, days to physiological maturity, pod bearing zone, seed yield, bacterial blight and qualitative), plant growth type (plant growth habit, root system, main stem colour, stem hairiness, shape of hair, stem shape in cross section, stem fasciation, stem branching, branching pattern, leaf colour, leaf hairiness, leaf arrangement, middle leaf shape ,top leaf shape, basal leaf profile, basal leaf margin, lobe incision of basal leaf, leaf glands, leaf angle to main stem, petiole colour, petiole hairiness, shape of petiole hair, number of flowers per leaf axil, extra-floral

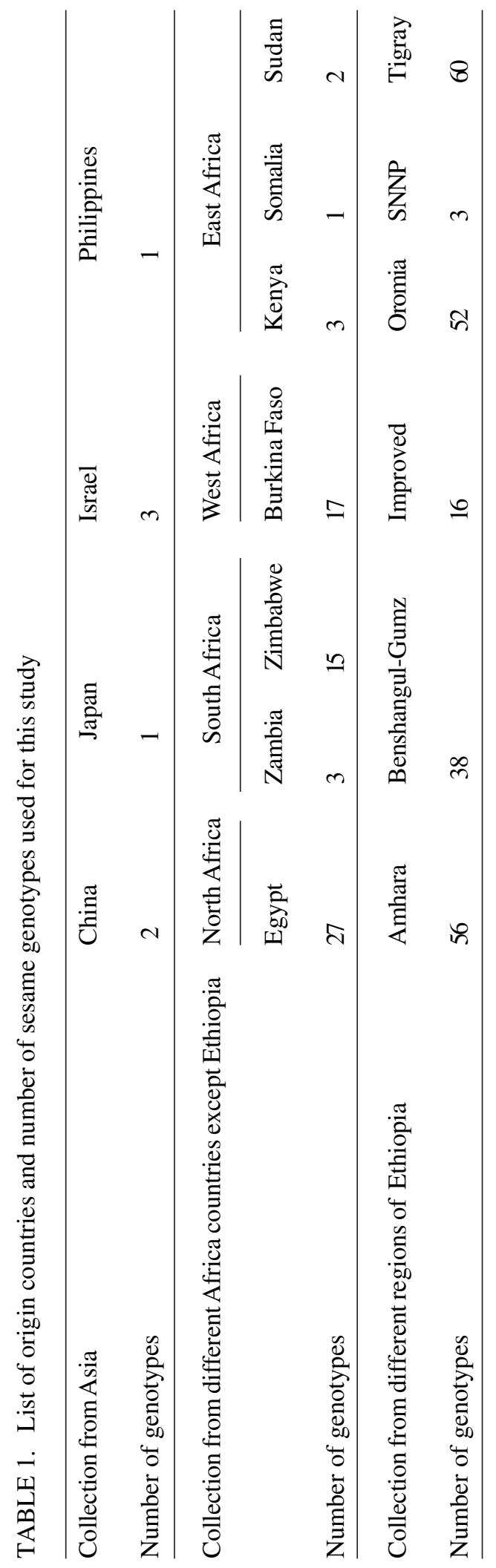


nectary development, extra-floral nectar colour, calyx tip colour, calyx hairiness, shape of calyx hair, corolla hairiness, shape of corolla hair, exterior corolla colour, interior corolla colour, corolla interior pigmentation, lower lip colour, absence/presence of foveolar, anther filament colour, anther connective tip gland, style length, number of carpels per capsule, bicarpellate capsule shape, capsule arrangement, capsule hairiness, shape of capsule hair, anthocyanin colouration of capsule, colour of dry capsules, capsule dehiscence at ripening, type of capsule beak, and thickness of capsule mesocarp data) were recorded according to the sesame descriptors list of IPGRI and NBPGR (IPGRI and NBPGR, 2004).

All measurements were done after tagging five randomly selected plant in each plot. Yield, growth period, plant and capsule variation and disease reactions, were recorded using standard procedures (IPGRI and NBPGR, 2004). The early flowering dates were recorded as the number of days from sowing to observation of the first flower on $50 \%$ of the individuals. Flower and leaf-related traits (days to flower initiation, days to $50 \%$ flowering and days to physiological maturity) were observed and measured in the full-bloom stage. After harvesting manually, yield-related traits (Number of carpels per capsule, Seeds per capsule, 1000-seed weight and seed yield) were measured in the laboratory. Seed yield was collected per plot and later converted into metric tonnes per hectare.

\section{Data analysis}

Analysis of variance. Data obtained from the different environments were analysed separately, and thereafter combined for after the error homogeneity test, conducted between testing locations using SAS computer software (SAS, 2002). Statistically significant genotype means were separated using LSmeans package of SAS at $\mathrm{P}<0.05$ level.

Multivariate analyses, including Cluster Analysis and Principal Component Analysis, were used to group the 300 sesame genotypes into respective categories. The Principal Components Analyses were meant to identify large contributing traits to the total variation among the populations. Hierarchal clustering of accessions based on the Average Linkage Method were performed using JMP SAS software (JMP®, 2002) to group sesame genotypes. Statistics, pseudo F statistic and pseudo 12 statistic generated by SAS were examined to decide the number of optimum clusters.

Divergence analysis. The patterns of distribution of morphological variation were analysed using Mahalanobis Generalised Distances $\left(\mathrm{D}^{2}\right)$. The $\mathrm{D}^{2}$ were applied to estimate the distances between and within clusters, using the SAS computer software package as per the following formula:

$D^{2} i j=(X i-X j)^{\prime} S^{-1}(X i-X j)$

Where:

$D^{2} \mathrm{ij}$ is the distance between class $\mathrm{i}$ and $\mathrm{j} ; \mathrm{Xi}$ and $\mathrm{Xj}$ are the vector means of the traits for the $\mathrm{i}^{\text {th }}$ and $\mathrm{j}^{\text {th }}$ groups, and $\mathrm{S}^{-1}$ is the inverse of the pooled covariance matrix.

The $\mathrm{D}^{2}$ analysis was based on the mean values of all morphological traits across locations. The D2 values obtained for pairs of clusters were considered as the calculated values of Chi-square $\left(\chi^{2}\right)$ and were tested for significance at $\mathrm{P}<5 \%$ against the tabulated value of $\chi^{2}$ for ' $\mathrm{P}$ ' degree of freedom, where $\mathrm{P}$ is the number of parameters considered (Singh et al, 1985).

Principal Component Analysis. Principal components based on correlation matrix, and Euclidian distances were calculated using PAST software (Hammer et al., 2001). One of the major reasons that analyses of principal components on correlation matrix was to standardise each variate (by subtracting its mean and dividing by its standard deviation), which is useful as the parameters considered 
in this study did not share a common scale of measurement. Principal components having Eigen values $>1$ were considered as significant and presented in the results.

\section{RESULTS}

Morphological characteristics. All genotypes showed wide ranges of variation for most of the morphological traits studied; except plant growth type, leaf glands, anther filament colour, anther connective tip gland and anthocyanin colouration of capsule (Table 2). All tested genotypes consisted of the plants with shattering and indeterminate growth habits. There was only white anther filament colour and absence of leaf glands and anther connective tip gland. Most of the genotypes had one flower per axil $(95.64 \%)$. Of the 300 sesame genotypes, only 13 that were introduced from one of the African countries, Egypt had three flowers per axil.

There were large variations in stem, leaf, calyx, capsule and corolla hairiness among the accessions (Table 2). Most of the genotypes showed glabrous (hair absent) and weak or sparse hairiness; and short and straight shape of hair of stem, petiole and capsule. Strong or profuse hair was observed in a few genotypes (Table 2); on the other hand, uniqueness of hairiness and shape of hair of stem, petiole and capsule were recorded on certain genotypes that were introduced from Egypt.

There were large variations in sesame branching across all genotypes (Table 2), with $88.09 \%$ for Ternate, $1.36 \%$ for Alternate, $3.4 \%$ for Opposite and $7.48 \%$ as mixed branching patterns. All 21 genotypes that recorded mixed branching pattern were introduced from different African countries; and out of 21 germplasm, 13 were from Egypt alone. Some genotypes had Tetracarpellate capsule structure. (Table 2).

Yield and yield components. There were significant differences $(\mathrm{P}<0.05)$ among the study genotypes for yield and yield components; with the exception of number of secondary branches, petiole length at middle leaf, mean capsule width and mean capsule thickness (Table 3).

The maximum values for days to flower initiation, days to $50 \%$ flowering and days to maturity were 72, 82 and 128 days, respectively. The highest seed yield was found in 9026 genotypes collected from BenshangulGumz Region. The average seed yield was $0.52 \mathrm{t} \mathrm{ha}^{-1}$ with a range of 0.034 and $1.24 \mathrm{t}$ $\mathrm{ha}^{-1}$. The mean and range values of all quantitative characters are presented in Table 3.

Cluster analysis. The 300 genotypes were grouped into 6 clusters based on 22 sesame parameters (Fig. 1). Five of the six clusters comprised of more than one germplasm; whereas one cluster was singleton (containing single accession). Cluster 1 contained 115 genotypes $(38.3 \%)$ out of 300 ; and was followed by clusters II, V, IV and III containing 107, 36, 31 and 10 accessions, respectively .Whereas the cluster VI contained only one genotype $(0.33 \%)$.

Cluster I constituted the largest number of germplasm, mainly collected from the different regions of Ethiopia 73(64.34\%); namely Amhara $(n=36)$, Benshangul-Gumz (11), Oromia (4), Tigray (22) and 1 improved variety, $35(30.43 \%)$. Those registered as introduced from different African countries included Burkina Faso (8), Egypt (10), Kenya (1), Somalia (1), Sudan (1), Zambia (1) and Zimbabwe (13). The remaining 6 genotypes were introduced from different Asian countries.

Most genotypes of Cluster II were collected from the different regions of Ethiopia 93(86\%); - Amhara ( $\mathrm{n=9}$ ), Benshangul-Gumz (21), Oromia (35), SNNP (2), Tigray (26) and 10 improved varieties. Only 4 genotypes were introduced from three African countries; namely Burkina Faso (2), Egypt (1) and Kenya (1) belonged to Cluster II. All genotypes of Cluster III were collected from three different regions of Ethiopia; namely Amhara $(n=4)$, Oromia (3), Tigray (2) and 1 improved variety. 
TABLE 2. Predominant morphological characters for the sesame genotypes used in a study in Ethiopia

\begin{tabular}{|c|c|c|c|c|c|}
\hline \multirow{2}{*}{$\begin{array}{l}\text { Plant growth type } \\
\text { Plant growth habit }\end{array}$} & \multicolumn{5}{|c|}{$100 \%$ Indeterminate } \\
\hline & $0.3 \%$ Prostrate & $0.3 \%$ Semi-erect & $99.32 \%$ erect & & \\
\hline Root system & Shallow fibrous & $\begin{array}{l}94.01 \% \text { Deep thin } \\
\text { taproot }\end{array}$ & $\begin{array}{l}5.63 \% \text { Tuberous thick } \\
\text { taproot }\end{array}$ & & \\
\hline Main stem colour & $0.36 \%$ Green & $50 \%$ Yellow & $1.07 \%$ Purplish green & 48.20 Purple & $0.36 \%$ Other \\
\hline Stem hairiness & $\begin{array}{l}0.35 \% \text { Glabrous } \\
\text { (hair absent) }\end{array}$ & $96.52 \%$ Weak or sparse & $2.09 \%$ Medium & $\begin{array}{l}1.05 \% \text { Strong or } \\
\text { profuse }\end{array}$ & \\
\hline Shape of hair & $\begin{array}{l}97.19 \% \text { Short and } \\
\text { straight }\end{array}$ & $\begin{array}{l}2.10 \% \text { Medium and } \\
\text { straight }\end{array}$ & $0.7 \%$ Long and bent & & \\
\hline Stem shape in cross section & $0.7 \%$ Round & $99.3 \%$ Square & & & \\
\hline Stem fasciation & 99.3\% Absent & $0.7 \%$ Present & & & \\
\hline Stem branching & $3.4 \%$ Opposite & $1.36 \%$ Alternate & $88.09 \%$ Ternate & 7.48\% Mixed & \\
\hline Branching pattern & $4.60 \%$ Non-branching & $16.31 \%$ Basal branching & $31.91 \%$ Top branching & $47.16 \%$ Other & \\
\hline Leaf colour & $40.88 \%$ Green & $\begin{array}{l}18.24 \% \text { Green with } \\
\text { yellowish cast }\end{array}$ & $\begin{array}{l}40.20 \% \text { Green with blue- } \\
\text { gray cast }\end{array}$ & $\begin{array}{l}0.67 \% \text { Green with purple } \\
\text { cast }\end{array}$ & \\
\hline Leaf hairiness & $\begin{array}{l}82.37 \% \text { Glabrous } \\
\text { (hair absent) }\end{array}$ & $17.62 \%$ Weak or sparse & & & \\
\hline Leaf arrangement & 4.73\% Opposite & 18.92\% Alternate & $8.11 \%$ Ternate & 68.24\% Mixed & \\
\hline Leaf shape (middle) & Linear & $31.9 \%$ Lanceolate & $0.34 \%$ Elliptic & $67.69 \%$ Ovate & \\
\hline Leaf shape (Top) & $30.45 \%$ Linear & $69.55 \%$ Lanceolate & Elliptic & Ovate & \\
\hline Basal leaf profile & $13.17 \%$ Flat & $\begin{array}{l}\text { 4.73\% Cup shaped } \\
\text { (concave) }\end{array}$ & $\begin{array}{l}82.09 \% \text { Reverse cup } \\
\text { shaped (convex) }\end{array}$ & & \\
\hline Basal leaf margin & $5.76 \%$ Entire & 93.22\% Serrate & $1.02 \%$ Dentate & & \\
\hline Lobe incision of basal leaf & $\begin{array}{l}6.84 \% \text { Absent } \\
\text { (leaf entire) }\end{array}$ & $2.74 \%$ Weak & 26.71\% Medium & $\begin{array}{l}63.7 \% \text { Strong (three or } \\
\text { more lobes) }\end{array}$ & \\
\hline Leaf glands & $100 \%$ Absent & & & & \\
\hline
\end{tabular}


TABLE 2. Contd.

\begin{tabular}{|c|c|c|c|c|c|}
\hline \multicolumn{3}{|l|}{ Plant growth type } & \multicolumn{3}{|l|}{$100 \%$ Indeterminate } \\
\hline Leaf angle to main stem & $16.55 \%$ Acute $\left(<90^{\circ}\right)$ & $\begin{array}{l}83.11 \% \text { Horizontal } \\
\left(=90^{\circ}\right)\end{array}$ & & & \\
\hline Petiole colour & $21.33 \%$ Green & $33.92 \%$ Greenish purple & 40.56\% Purple & 4.19\% Pink & \\
\hline Petiole hairiness & $\begin{array}{l}2.09 \% \text { Glabrous } \\
\text { (hair absent) }\end{array}$ & $96.15 \%$ Weak or sparse & 1.39\% Medium & $\begin{array}{l}0.35 \% \text { Strong or } \\
\text { profuse }\end{array}$ & \\
\hline Shape of petiole hair & $\begin{array}{l}98.21 \% \text { Short and } \\
\text { straight }\end{array}$ & $\begin{array}{l}1.43 \% \text { Medium and } \\
\text { straight }\end{array}$ & $0.36 \%$ Long and bent & & \\
\hline $\begin{array}{l}\text { Number of flowers per leaf axil } \\
\text { Extra-floral nectary development } \\
\text { Extra-floral nectar colour } \\
\text { Calyx tip colour }\end{array}$ & $\begin{array}{l}95.64 \% \text { One } \\
0.34 \% \text { Rudimentary } \\
0.34 \% \text { Light yellow } \\
3.31 \% \text { Green }\end{array}$ & $\begin{array}{l}\text { 4.36\% More than one } \\
59.12 \% \text { Small } \\
99.66 \% \text { Yellow } \\
96.69 \% \text { Purple }\end{array}$ & $39.18 \%$ Medium & $1.35 \%$ Large & \\
\hline Calyx hairiness & $\begin{array}{l}0.83 \% \text { Glabrous } \\
\text { (hair absent) }\end{array}$ & $97.93 \%$ Weak or sparse & $1.24 \%$ Medium & & \\
\hline Shape of calyx hair & $\begin{array}{l}\text { 99.58\% Short and } \\
\text { straight }\end{array}$ & $\begin{array}{l}0.42 \% \text { Medium and } \\
\text { straight }\end{array}$ & & & \\
\hline Corolla hairiness & $\begin{array}{l}35.37 \% \text { Weak or } \\
\text { sparse }\end{array}$ & 37.75\%Medium & $26.87 \%$ Strong or profuse & & \\
\hline Shape of corolla hair & $\begin{array}{l}38.09 \% \text { Short and } \\
\text { straight }\end{array}$ & $\begin{array}{l}40.47 \% \text { Medium and } \\
\text { straight }\end{array}$ & $21.43 \%$ Long and bent & & \\
\hline Exterior corolla colour & $6.78 \%$ White & $\begin{array}{l}70.85 \% \text { White with pink } \\
\text { shading }\end{array}$ & $\begin{array}{l}22.37 \% \text { White with deep } \\
\text { pink shading }\end{array}$ & & \\
\hline Interior corolla colour & $13.65 \%$ White & $\begin{array}{l}60.75 \% \text { White with pink } \\
\text { shading }\end{array}$ & $\begin{array}{l}25.59 \% \text { White with deep } \\
\text { pink shading }\end{array}$ & & \\
\hline Corolla interior pigmentation & $4.41 \%$ Absent & $\begin{array}{l}31.86 \% \text { Pigmented } \\
\text { throughout }\end{array}$ & $\begin{array}{l}49.83 \% \text { Pigmentation } \\
\text { alon gthe lip region of } \\
\text { corolla tube }\end{array}$ & $\begin{array}{l}4.40 \% \text { Pigmentation } \\
\text { in the supra foveolate } \\
\text { region }\end{array}$ & $\begin{array}{l}9.49 \% \text { Pigmentation in the } \\
\text { infra foveolate region }\end{array}$ \\
\hline
\end{tabular}


Plant growth type

$100 \%$ Indeterminate

Lower lip colour

Absence/presence of foveolar

Anther filament colour

Anther connective tip gland

Style length

umber of carpels per capsule

Bicarpellate capsule shape

Capsule arrangement

Capsule hairiness

Shape of capsule hair

Anthocyanin colouration of

capsule

Colour of dry capsules

Capsule dehiscence at ripening

Type of capsule beak

Thickness of capsule mesocarp
16.27\% Colourless $\quad 83.73 \%$ Coloured

99.66\% Absent $\quad 0.34 \%$ Present

$100 \%$ White

$100 \%$ Absent

1\% Short (stigma $\quad 96.99 \%$ Medium

terminating below the (stigma position at

position of anthers) anther's level)

98.99\% Bicarpellate $\quad 0.66 \%$ tricarpellate

$24.49 \%$ Narrow oblong $75.51 \%$ Broad oblong

95.65\% Monocapsular $4.35 \%$ Multicapsular

$97.32 \%$ Weak or sparse $2.67 \%$ Medium

96.98\% Short and $\quad 3.02 \%$ Medium and

straight

straight

$100 \%$ Present

29.89\% Straw/yellow $\quad 69.56 \%$ Brown/tan

$15.05 \%$ Partially

shattering

99.33\% Curved

$84.95 \%$ Completely

0.54\% Purple

$2 \%$ Long (stigma

protruding outside

the position of anthers)

$0.33 \%$ Tetracarpellate

$0.67 \%$ Cleft

$1.09 \%$ Thick 
TABLE 3. Range of variation and F- value of analysis of variance for quantitative characters in sesame genotypes

\begin{tabular}{lrrrrl}
\hline Character & Min & Max & Mean & Range & F Value \\
\hline PTH & 47.36 & 181.32 & 136.81 & 133.96 & $2.56^{* * * *}$ \\
PBR & 0.12 & 6.5 & 3.5 & 6.38 & $2.16^{* * * *}$ \\
SBR & 0 & 2.2 & 0.37 & 2.2 & 1 \\
LBL & 5.51 & 13.72 & 9.91 & 8.21 & $1.34 * *$ \\
WBL & 2.51 & 9.52 & 6.76 & 7.01 & $1.54 * * *$ \\
LML & 5.49 & 12.68 & 9.3 & 7.19 & $1.84 * * *$ \\
WML & 2 & 6.44 & 3.53 & 4.44 & $1.42^{* * *}$ \\
LTL & 3.67 & 7.25 & 5.17 & 3.58 & $1.36^{* * *}$ \\
WTL & 0.46 & 7.25 & 0.72 & 6.79 & $1.31^{* *}$ \\
PLBL & 2.84 & 8.44 & 5.89 & 5.6 & $1.46^{* * *}$ \\
PLML & 0.95 & 4.67 & 2.67 & 3.72 & 1.04 \\
PLTL & 0.24 & 1.44 & 0.47 & 1.2 & $1.89^{* * *}$ \\
DFI & 30 & 72 & 49.28 & 42 & $1.37 * * *$ \\
DF & 35 & 82 & 53.76 & 47 & $1.35^{* *}$ \\
NCPP & 7.14 & 57.06 & 34.33 & 49.92 & $2.29 * * *$ \\
CAPL & 2.01 & 3.81 & 2.83 & 1.8 & $2.47 * * *$ \\
CW & 0.55 & 1.01 & 0.71 & 0.46 & 1.15 \\
CT & 0.33 & 0.74 & 0.5 & 0.41 & 1.06 \\
SPC & 48.44 & 82.4 & 67.36 & 33.96 & $1.4 * * *$ \\
TSW & 1.66 & 3.33 & 2.25 & 1.67 & $2.32^{* * *}$ \\
DM & 79 & 128 & 103.57 & 49 & $1.73^{* * *}$ \\
PBZ & 20.56 & 83.46 & 45.24 & 62.9 & $2.67 * * *$ \\
YLD & 0.034 & 1.24 & 0.52 & 1.204 & $3.95^{* * *}$ \\
BBL & 8.64 & 69.1 & 21.3 & 60.46 & $1.54 * * *$ \\
\hline
\end{tabular}

$\mathrm{PTH}=$ plant height in centimeter; $\mathrm{PBR}=$ primary branch; $\mathrm{LBL}=$ length of basal leaf; $\mathrm{WBL}=$ width of basal leaf ; $\mathrm{LML}=$ length of middle leaf; $\mathrm{WML}=$ width of middle leaf $; \mathrm{LTL}=$ length of top leaf $\mathrm{WTL}=$ width of top leaf; PLBL = petiole length of basal leaf; PLTL = petiole length of top leaf ; DFI = days to flower initiation; $\mathrm{DF}=$ days to $50 \%$ flowering $; \mathrm{COL}=$ corolla length; $\mathrm{LLL}=$ length of longest lip; NCPP $=$ Number of capsules per plant CAPL = capsule length; $\mathrm{SPC}=$ seeds per capsule; TSW = 1000 seed weight in gram; $\mathrm{DM}=$ days to maturity; $\mathrm{PBZ}=$ Pod bearing zone; $\mathrm{YLD}=$ yield in tonnes per hectare; $\mathrm{BBL}=$ bacterial blight reaction. $* *$ Significant at $\mathrm{P}<0.01 ; * * *$ Significant at $\mathrm{P}<0.001$

Most genotypes of Cluster IV were collected from different countries of Africa $22(70.96 \%)$ (Burkina Faso (6), Egypt (12), Sudan (1), Zambia (2) and Zimbabwe (2)); and 9 genotypes were collected from three regions of Ethiopia (Oromia (4), SNNP (1) and Tigray (4)).

Cluster V consisted of genotypes mainly collected from different regions of Ethiopia 29 (80.55 (Amhara ( $\mathrm{n}=7)$, Benshangul-Gumz (5), Oromia (6) and Tigray (6); and 4 were improved varieties. Only 7 genotypes were introduced from three African countries; namely Burkina Faso (2), Egypt (4) and Kenya (1). The remaining one genotypes was from Israel. Cluster VI consist only one genotype collected from Benshangul-Gumz from Ethiopia.

Cluster mean analysis. The clusters for different traits indicated wide variations for all the characters considered (Table 4). The 
Hierarchical Clustering

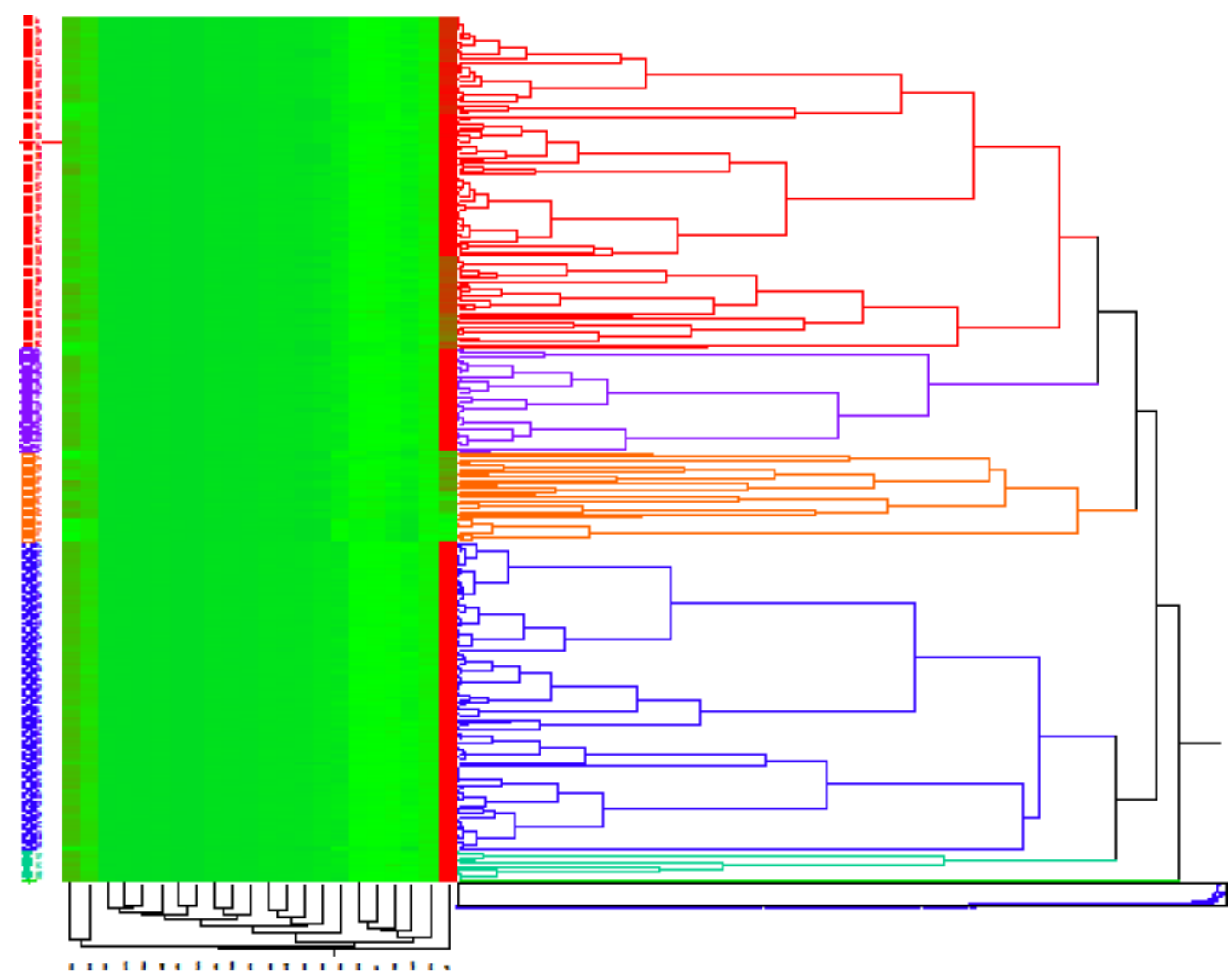

Figure 1. Dendrogram of 300 sesame genotypes based on average linkage hierarchical cluster analysis between groups of sesame in Ethiopia.

highest values for grain yield were recorded from Cluster VI $\left(1.24 \mathrm{t} \mathrm{ha}^{-1}\right)$ and the lowest from Custer IV $\left(0.132 \mathrm{t} \mathrm{ha}^{-1}\right)$. The next highest yield to Cluster VI were recorded by Cluster III $\left(0.973 \mathrm{t} \mathrm{ha}^{-1}\right)$. Clusters means for all characters in sesame genotypes presented in Table 4.

Divergence analysis. Pair wise generalised squared distances (D2) among six clusters are presented in Table 5. There were 15 possible pair wise genetic distances between any two clusters. Among these, only 4 genetic distances (between clusters I and IV, I and V, II and III, II and V) were not significant $(\mathrm{P}>0.05)$; but the remaining genetic distances were highly significant $(\mathrm{P}<0.01)$. The maximum distance was found between clusters IV and VI (D2 $=342.56$ ), and the distances between I, IV and V clusters with cluster VI and cluster II and III with IV were maximum and very highly significant $(\mathrm{P}<0.01)$.

Principal Component Analysis (PCA). The first five principal components were found to be significant (Eigen value greater than 1) and accounted for about $75.4 \%$ of the total variation (Table 6). The first PCA component explained $34.8 \%$ of the total variance; while the first and second PCA components accounted for $54.6 \%$ of the variation (Fig. 2). Parameters that contributed relatively more with an Eigen vector value for the first PCA were plant height, length and width of basal leaf, petiole 
TABLE 4. Cluster means for parameters in sesame genotypes used in a study of sesame germplasm conducted in Ethiopia

\begin{tabular}{|c|c|c|c|c|c|c|c|}
\hline \multirow[t]{2}{*}{ Parameters } & \multicolumn{7}{|c|}{ Cluster } \\
\hline & I & II & III & IV & V & VI & GM \\
\hline PTH & 125.6 & 142.48 & 149.8 & 105.1 & 133.47 & 144.32 & 133.46 \\
\hline PBR & 3.35 & 3.17 & 3.26 & 3.13 & 2.99 & 6.08 & 3.66 \\
\hline LBL & 10.31 & 10.63 & 11.24 & 8.37 & 10.31 & 10.52 & 10.23 \\
\hline WBL & 6.76 & 6.96 & 7.35 & 5.4 & 6.76 & 6.61 & 6.64 \\
\hline LML & 9.43 & 9.96 & 10.85 & 7.78 & 9.71 & 9.42 & 9.52 \\
\hline WML & 3.94 & 3.8 & 3.87 & 3.4 & 3.9 & 4.16 & 3.85 \\
\hline LTL & 5.32 & 5.3 & 5.5 & 4.96 & 5.39 & 5.24 & 5.28 \\
\hline WTL & 0.8 & 0.82 & 0.83 & 0.99 & 0.84 & 0.96 & 0.87 \\
\hline PLBL & 5.81 & 6.2 & 6.61 & 4.3 & 5.98 & 6.52 & 5.9 \\
\hline PLTL & 0.51 & 0.52 & 0.57 & 0.69 & 0.57 & 0.43 & 0.55 \\
\hline DFI & 48.21 & 46.54 & 45.07 & 49.38 & 45.77 & 48 & 47.16 \\
\hline $\mathrm{DF}$ & 52.81 & 50.74 & 49.03 & 53.1 & 50.42 & 53.33 & 51.57 \\
\hline $\mathrm{COL}$ & 13.17 & 16.45 & 16.27 & 8.21 & 14.58 & 16.37 & 14.18 \\
\hline$\amalg$ & 7.89 & 9.85 & 10.12 & 4.85 & 8.9 & 10.07 & 8.62 \\
\hline NCPP & 31.47 & 38.85 & 45.2 & 21.71 & 34.41 & 51.36 & 37.17 \\
\hline CAPL & 2.94 & 2.85 & 2.95 & 2.63 & 2.86 & 2.38 & 2.77 \\
\hline SPC & 68.92 & 69.36 & 68.14 & 63.3 & 68.74 & 63.8 & 67.04 \\
\hline TSW & 2.33 & 2.3 & 2.45 & 2.17 & 2.43 & 2.62 & 2.38 \\
\hline DM & 100.46 & 99.54 & 98.46 & 100.75 & 97.85 & 110 & 101.18 \\
\hline PBZ & 42.79 & 52.95 & 58.27 & 33.62 & 48.32 & 45.48 & 46.91 \\
\hline YLD & 0.393 & 0.771 & 0.973 & 0.132 & 0.569 & 1.24 & 0.679 \\
\hline BBL & 24.34 & 17.08 & 18.1 & 34.46 & 21.73 & 9.14 & 20.81 \\
\hline
\end{tabular}

$\mathrm{PTH}=$ plant height in centimeter; $\mathrm{PBR}=$ primary branch $\mathrm{LBL}=$ length of basal leaf; $\mathrm{WBL}=$ width of basal leaf; $\mathrm{LML}=$ length of middle leaf; WML = width of middle leaf ; LTL = length of top leaf ; WTL $=$ width of top leaf; PLBL = petiole length of basal leaf; PLTL $=$ petiole length of top leaf $; \mathrm{DFI}=$ days to flower initiation; $\mathrm{DF}=$ days to 50\% flowering; $\mathrm{COL}=$ corolla length; $\mathrm{LLL}=$ length of longest lip; $\mathrm{NCPP}=$ Number of capsules per plant $\mathrm{CAPL}=$ capsule length; $\mathrm{SPC}=$ seeds per capsule $; \mathrm{TSW}=1000$ seed weight; $\mathrm{DM}=$ days to maturity; $\mathrm{PBZ}=$ pod bearing zone; $\mathrm{YLD}=$ yield in tonnes per hectare; $\mathrm{BBL}$ $=$ bacterial blight reaction

length of basal leaf, number of capsule per plant and grain yield. Most of the variations attributed to the second PCA were contributed by length of middle and top leaf, petiole length of top leaf and pod bearing zone.

The third PCA explained about $9.5 \%$ of the variation traits, such as width of middle leaf, capsule length and bacterial blight reaction contributed much of its variation (Fig. 2). The fourth PCA were explained by corolla length, length of the longest lip and seed per capsule; while the fifth PCA explained by 1000 seed weight.

\section{DISCUSSION}

Morphological characteristics. There was a high genetic variability among the tested genotypes for most of the evaluated traits that showed the potential of these genotypes for the sesame breeding programme to improve grain yield through direct selection and 
TABLE 5. Intra- (bolded diagonals) and inter-cluster distance between sesame genotypes categorised into clusters

\begin{tabular}{lrrrrrr}
\hline From class & \multicolumn{5}{c}{ Generalised Squared Distance to class } \\
\cline { 2 - 6 } & I & II & III & IV & V & VI \\
\hline I & & & & & & \\
II & 41.14 & & & & & \\
III & 97.6344 & 14.6981 & & & \\
IV & 19.7745 & 108.429 & 190.871 & & \\
V & 10.0594 & 12.566 & 48.6915 & 52.3529 & & \\
VI & 217.978 & 88.4217 & 50.936 & 342.561 & 149.602 & \\
\hline
\end{tabular}

$\mathrm{X}^{2}=38.932$ at $1 \%$ probability level and $\mathrm{X}^{2}=32.671$ at $5 \%$ probability level

TABLE 6. Eigen vectors, explained variance and Eigen values of the first significant Principal components for parameters of sesame genotypes

\begin{tabular}{|c|c|c|c|c|c|}
\hline \multirow[t]{2}{*}{ Parameter } & \multicolumn{5}{|c|}{ Eigen vectors } \\
\hline & PCA1 & PCA2 & PCA3 & PCA4 & PCA5 \\
\hline Plant height & 0.304 & -0.09 & -0.124 & 0.002 & 0.068 \\
\hline Primary branch & 0.147 & -0.292 & -0.048 & -0.251 & 0.123 \\
\hline Length of basal leaf & 0.296 & 0.117 & 0.209 & -0.001 & 0.108 \\
\hline Width of basal leaf & 0.294 & 0.028 & 0.229 & -0.121 & 0.074 \\
\hline Length of middle leaf & 0.222 & 0.241 & 0.09 & -0.281 & -0.06 \\
\hline Width of middle leaf & 0.121 & 0.069 & 0.296 & -0.407 & -0.424 \\
\hline Length of top leaf & 0.035 & 0.304 & 0.217 & -0.179 & -0.009 \\
\hline Width of top leaf & -0.19 & 0.201 & 0.035 & -0.316 & -0.055 \\
\hline Petiole length of basal leaf & 0.276 & 0.082 & 0.107 & -0.206 & 0.156 \\
\hline Petiole length of top leaf & -0.236 & 0.21 & 0.011 & -0.153 & -0.136 \\
\hline Days to flower initiation & 0.156 & -0.368 & 0.15 & -0.027 & -0.171 \\
\hline Days to $50 \%$ flowering & 0.162 & -0.384 & 0.122 & -0.068 & -0.121 \\
\hline Corolla length & 0.277 & 0.07 & 0.006 & 0.354 & 0.012 \\
\hline Length of longest lip & 0.278 & 0.069 & -0.013 & 0.351 & 0.001 \\
\hline Number of capsules per plant & 0.222 & 0.07 & -0.399 & -0.18 & -0.096 \\
\hline Capsule length & 0.092 & 0.261 & 0.331 & 0.265 & -0.107 \\
\hline Seeds per capsule & 0.143 & 0.152 & 0.099 & 0.318 & -0.521 \\
\hline 1000 seed weight & 0.118 & 0.073 & 0.323 & -0.005 & 0.589 \\
\hline Days to maturity & 0.173 & -0.371 & 0.018 & -0.101 & -0.083 \\
\hline Pod bearing zone & 0.178 & 0.269 & -0.347 & -0.054 & 0.055 \\
\hline Grain yield & 0.209 & 0.205 & -0.351 & -0.092 & 0.093 \\
\hline Bacterial blight & -0.278 & -0.017 & 0.258 & 0.045 & 0.18 \\
\hline Eigenvalue & 7.672 & 4.3453 & 2.1004 & 1.3935 & 1.0867 \\
\hline Explained variance $\%$ & 34.9 & 19.8 & 9.5 & 6.3 & 4.9 \\
\hline Cumulative variance & 34.9 & 54.6 & 64.2 & 70.5 & 75.4 \\
\hline
\end{tabular}

PCA= Principal component analysis 


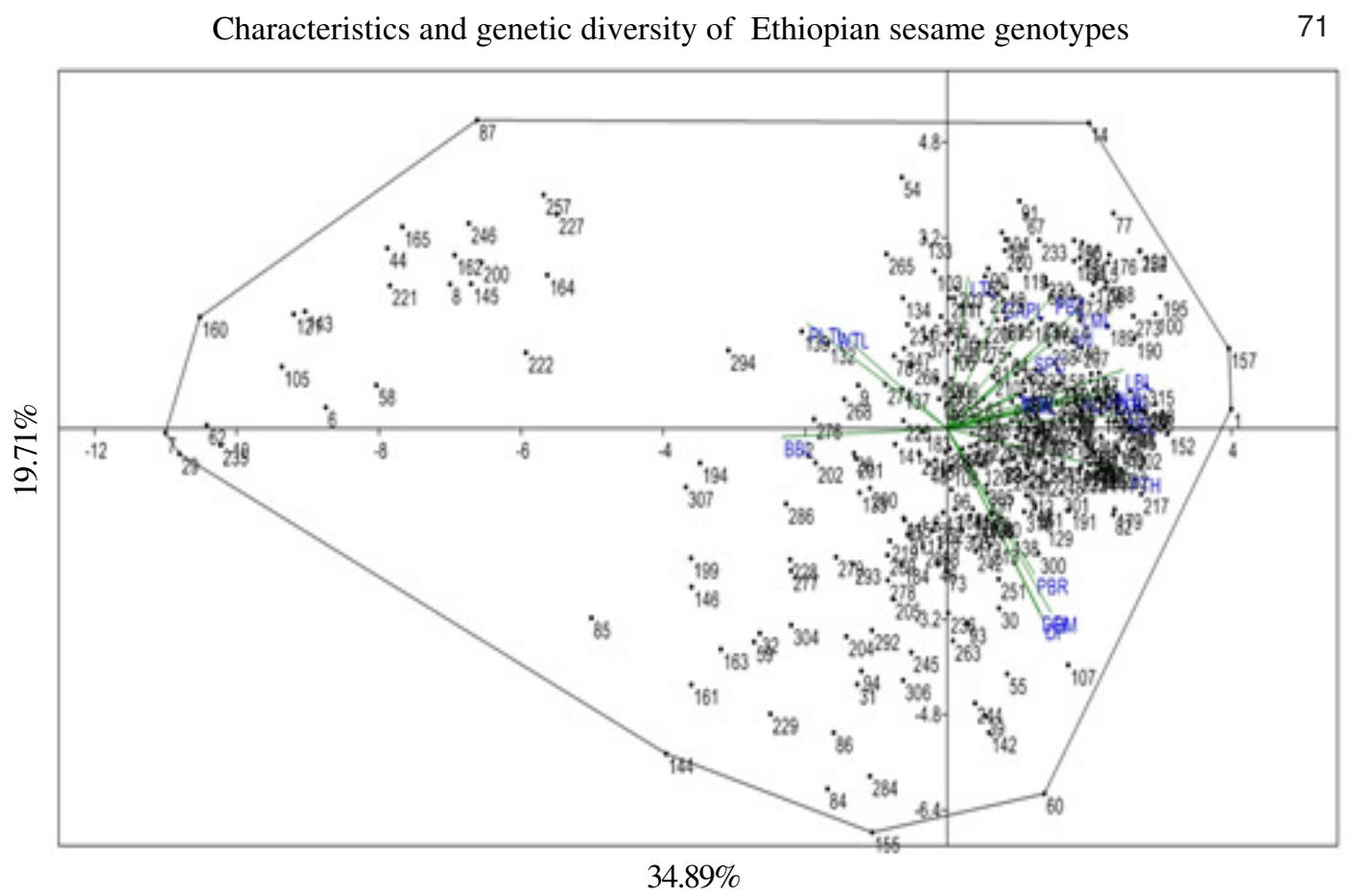

Figure 2. Biplot of PC1 and PC2 showing the overlay of 300 genotypes and the 22 studied parameters. Note: The black color represents the germplasms $(n=300)$ and the blue color represents the parameters under the study.

crossing among variable potential genotypes (Table 2). Among the evaluated traits, grain yield showed high variabilities that can be used for direct selection for release and producing potentially high yielder segregation populations through crossing form different origins. Similar results were reported on 10 morphological and 11 agronomic descriptors of sesame (Uzun and Çaðýrgan, 2006;Furat and Uzun, 2010).

Number of flowers per leaf axil (number of capsule per plant) is one of the important characters for plant breeding programmes since it provides sufficient seed per cross for subsequent evaluation activities. In our study, the 13 sesame genotypes introduced from Egypt gave up to three flowers per leaf axil that showed the potential of these genotypes in the future sesame breeding programmes in Ethiopia. The importance of this trait as a yield contributing character was emphased by (Osman, 1989; Ibrahim et al., 1983).

Large variations were observed in stem, leaf, calyx capsule and Corolla hairiness among the genotypes; ranging from glabrous to strong or profuse (Table 2). Uniqueness on the hairiness and shape of hair of stem, petiole and capsule were recorded on a certain number of genotypes that were introduced from Egypt. Since hairiness is a typical character of sesame and can be seen in many parts of the plant such as stem, leaf, corolla, and capsule (Weiss, 1983), and the trait has advantages for preventing insect pests and diseases of sesame, it also has positive effect in terms of preventing water loss, and is a desirable trait in breeding. Having this variation is important for further breeding programme.

Some genotypes had Tetracarpellate capsule structure (Table 2). This type of capsule potentially enlarges the space for more seeds to fit and a structural modification converting the two extra-floral nectaries to capsules (Bedigian, 2003). However, plants with Tetracarpellate capsules exhibit flatness on the stem, which is rarely seen in Bicarpellate sesame genotypes. 
Yield and yield components. The analysis of variance revealed statistically significant differences at 0.1 and $0.5 \%$ probability level among three hundred sesame genotypes for yield and yield component characters (Table 2), except for a certain characters (secondary branch, petiole length at middle (mid-level/midheight) leaf, mean capsule width and mean capsule thickness). This indicates the existence of substantial genetic variation among genotypes in all characters. This result agrees with the observation of Saha et al. (2012).

Genotype 203637 had the maximum values for flower initiation (72 days), days to $50 \%$ flowering ( 82 days), and days to maturity (128 days); while several early maturing germplasms existed in the collection (Table 1). These germplasms demonstrated the valuable resource available in the germplasm pool to be used in the breeding programmes to develop sesame genotypes adapted to different environments, as well as for studies on thermoand photo-period sensitivity (Suddihiyam et al., 1992; Aziz ur Rehman et al., 2009).

The mean seed yield was $0.52 \mathrm{t} \mathrm{ha}^{-1}$, with a range of 0.034 and $1.24 \mathrm{t} \mathrm{ha}^{-1}$. The mean and the ranges of the genotype values revealed a large genetic diversity useful for the development of varieties. The genotypes with a wide range of variation for agronomic characters had potential to determine the best genotypes for different environments.

Cluster analysis. The 300 sesame genotypes were grouped into 6 clusters containing significantly different numbers of sesame genotype, which ranged from 1 to 115 . Cluster $\mathrm{I}$ and $\mathrm{V}$ contained genotypes originating from two different continent countries. Even from the African continent (East, West, South and North Africa), from this we observed a close relationship between genotype from East Africa (majority from different regions of Ethiopia), South Africa, North Africa and West Africa to the genotype from Asia. Clusters II and IV contained genotypes from different countries of Africa that included different regions of Ethiopia. Genotypes from the same origin were not all grouped into the same cluster. This close genetic relationship observed might be due to the introduction of sesame into many countries and material exchange from widely separated locations (Kim et al., 2002). Moreover, the exchange of plant materials between Asia and East Africa dated back to a long time ago and still occurs (Zohary et al., 2012), with a steady increase in annual exportation of raw sesame seeds mainly for industrial applications.

The likelihood of crossover events between materials from different locations grown within the same area is high, knowing that cross-pollination in sesame has been reported to occur at a frequency between 5 and $60 \%$ (Wei et al., 2014). This crossing could explain the similarity of genotypes from the eastern part of Africa and Asia. Similar patterns have been observed by other researchers (Kim et al., 2002; Laurentin and Karlovsky, 2006; Park et al., 2011).

Cluster III contained genotypes originating from the same country, but from different three regions (Fig. 1). This result indicates the possibility of exchange of seeds, and seed trade between farmers, and gene flow across boundaries of those areas (Forsberg et al., 2015). The last cluster contained one genotype from Benshangul-Gumz. This might indicate that the genotype from Benshangul-Gumz was more diverse than others. The distribution and pattern of genotype, over significantly different clusters from Africa and Asia major geographic origins, would suggest future collections of local genotypes in those geographic regions is importance, for future national and international collection mission in sesame.

Cluster mean analysis. The cluster mean for different traits (Table 4), suggested a wide range of variation for all the characters under the study. Based on Clusters VI and III, the highest mean values for grain yield were recorded from genotypes originating from Ethiopia; but based on clusters IV and I, the lowest mean value for grain yield were recorded from most genotypes introduced from 
different African and Asian countries. Several factors may contribute to this observation, including climatic reasons such as temperature (day/night), day length, light intensity, precipitation, altitude and latitude. Photosynthesis is influenced by various biotic and abiotic stresses during grain filling; therefore, decrease or increase photosynthesis capacity is a major limiting factor for yield and all yield components (Beheshti and fard, 2010). There are reasons to believe that the less performing germplasm from different African and Asia countries were not adjusted to the field conditions, and therefore, gave low yields in this study. Basu et al. (2009) also reported seed yield to be a complex trait governed by polygene, and therefore is influenced more by environmental factors.

Our observation is in agreement with previous studies, in which sesame was shown to be highly sensitive to day length since it is a short day plant (Narayanan and Reddy, 1982). Suddihiyam et al. (1992) also reported about the significant interactions temperature and day length had on the flowering rate. According to them, yield depends on the interactions of different climatic parameters such as solar radiation, temperature, humidity relative to photosynthetically active radiation (PAR) (Beech and Ashri, 1985; Nath et al., 2001). (Yadav et al. (1988) also reported close correlations between PAR absorption and yield in sesame.

The germplasm listed in the clusters VI and VI were found valuable to be selected for use in breeding strategy to improve high yielding sesame genotypes.

Divergence analysis. The maximum distance among tested sesame genotypes lies between clusters IV and VI (D2 =342.56). Maximum genetic recombination and variation in the subsequent generation, is expected from crosses that involved parents from the clusters characterised by maximum distances. Thus, it could maximise opportunities for transgressive segregation, since a higher probability that unrelated genotype would contribute unique desirable alleles at different loci. Genetic distance, as a good indicator of transgression and heterosis, has been reported by several authors on many crops (Mulugeta and Hussein, 2013; Pickup et al., 2013). Hence, the attempt to cluster Ethiopian sesame genotypes using multivariate analyses, in the present study, is a significant precursor to initiating sesame breeding programme. However, the selection of parents for a particular cross should also consider the special advantages of each cluster and accession within a cluster, depending on specific objectives of hybridisation programmes.

Members within a cluster are assumed to be more closely related, in terms of trait under consideration than with members in different clusters (Million, 2012; Habtamu and Million, 2013). This indicates that superior hybrids or recombinants can be realised by mating between the lines of these clusters in a definite fashion. Crossing between genotypes belonging to the same cluster might not be expected to yield desirable segregates. This approach is, however, based on the assumption that suitable parents for crossing may be showing greater amount of genetic divergence. Further research on these selected germplasm will save a lot of time for the breeder in future.

Principal Component Analysis (PCA). Principal components analyses in this study showed that the first five PCAs explained about $75.4 \%$ of the variation (Table 6). The amount of explained variance by the first PCA and parameters that contributed relatively more, clearly indicated that grain yield and architectural traits of sesame are important traits that could be considered for sesame breeding and selection. Principal components analyses results indicated that the genotype lines studied had a considerable level of variability that could be exploited in future breeding programs. Hybridisation between genetically diverse genotypes in sesame to generate promising breeding material has been suggested by Alarmelu and Ramanathan, 1998. 
74

\section{CONCLUSION}

There is a considerable level of variability among sesame genotypes within the Ethiopian germplasm, as well as genotypes collected from elsewhere in Africa and Asia; a phenomenon that could be exploited in future breeding programmes. All genotypes are grouped into six clusters, with cluster I and II accounting for the largest number of genotypes. Greater genetic divergence is present between clusters IV and VI; followed by distances between clusters I and VI and cluster III with IV; indicating that superior hybrids or recombinants can be realised by mating between the lines of these clusters in a definite fashion. Their high yield potential can subsequently be combined with improvements of other traits such as plant height, number of capsule per plant, oil content, resistance to pests and disease.

The genotype originally collected from four regions of Ethiopia (Amhara, BenshangulGumz, Oromia and Tigray), specially genotype categorised under clusters VI and III, were found interesting and could be candidates for potential immediate breeding sources due to their high seed yield. Further research on these selected genotype will save a lot of time for the breeder in future. Morpho-agronomic traits have some shortcomings in evaluating genetic diversity as these are phenotypic markers and genetically distant genotypes may be morphologically similar. Further research should be done with molecular markers which can be used to determine genetic distance easily and successfully. DNA markers should provide more accurate measures of genetic similarity.

\section{ACKNOWLEDGEMENT}

The financial support of Amhara Agricultural Research Institute of (ARARI) and Gondar Agricultural Research Center through Sesame business network project, is appreciated. The local and exotic collections were kindly provided by Institute of Biodiversity
Conservation of Ethiopia and Different Federal and Regional research centers of Ethiopia.

\section{REFERENCES}

Abate, M. and Mekbib, F. 2015. Assesment of genetic variability and character association in Ethiopian low-altitude sesame (Sesamum Indicum L.) genotypes. Journal of Advanced Studies in Agricultural, Biological and Environmental Sciences 2:55-66.

Abate, M., Mekbib, F., Ayana, A. and Nigussie, M. 2015. Genetic variability and association of traits in mid- altitude sesame (Sesamum indicum L.) Germplasm of Ethiopia 9:114.

Adefris, T., Tadele, A. and Tesfaye, B. 2011. Sesame cultivation and use in Ethiopia. In: Bedigian D (ed) Sesame: the genus Sesamum. Medicinal and Aromatic Plants Industrial Profiles.

Alarmelu, S. and Ramanathan, T. 1998. Genetic divergence and heterosis in sesame (Sesamum indicum L.). Journal of Oilseeds Research 15:25-31.

Aziz Ur Rehman, Imran Habib, Nadeem Ahmad, Mumtaz Hussain, M. A. K. and Ali, J. F. 2009. Screening wheat germplasm for heat tolerance at terminal growth stage. Plant Omics Journal 2:9-19.

Basu, S.K., Acharya, S.N., Bandara, M.S., Friebel, D. and Thomas, J. E. 2009. Effects of genotype and environment on seed and forage yield in fenugreek (Trigonella foenum-graecum L.) grown in western Canada. Australian Journal of Crop Science 3:305-314.

Bedigian, D. 2003. Evolution of sesame revisited: Domestication, diversity and prospects. Genetic Resources and Crop Evolution 50:779-787.

Beech, D.F. and Ashri, A. 1985. Sesame: Research possibilities for yield improvement. FAO plant production and protection, Rome, Italy 
Beheshti, A.R. and Fard, B.B. 2010. Dry matter accumulation and remobilization in grain sorghum genotypes (Sorghum bicolor L. Moench) under drought stress. Australian Journal of Crop Science 4:185-189.

Borchani, C., Besbes, S., Blecker, C. and Attia, H. 2010. Chemical characteristics and oxidative stability of sesame seed, sesame paste, and olive oils. Journal of Agricultural Science and Technology 12:585-596.

CSA (Central Statistical Agency). 2019. Agricultural Sample Survey, 2018/19 Volume I: Report On Area and Production of Major Crops (Private peasant holdings, Meher season). . Statistical Bulletin 589, Addis Ababa, Ethiopia. 54pp.

Daniel, E.G. and Parzies, H.K. 2011. Genetic variability among landraces of sesame in Ethiopia. African Crop Science Journal 19:1-13.

Desawi hdru Teklu and Sentayehu Alamerew Kebede, D.E.G. 2014. Assessment of genetic variability, genetic advance, correlation and path analysis for morphological traits in sesame genotypes. Asian Journal of Agricultural Research 8:181-194.

Food and Agriculture Organization of the United Nations. 2017. FAOSTAT. Food and agriculture data.

Forsberg, N.E.G., Russell, J., Macaulay, M., Leino, M.W. and Hagenblad, J. 2015. Farmers without borders - genetic structuring in century old barley (Hordeum vulgare). Heredity 114:195-206. Nature Publishing Group.

Furat, S. and Uzun, B. 2010. The use of agromorphological characters for the assessment of genetic diversity in sesame (Sesamum indicum L.). Plant OMICS 3:85-91.

Gebremichael, D.E. 2017. Sesame (Sesamum indicum L.) breeding in Ethiopia. International Journal of Novel Research in Life Sciences 4:1-11.

Gidey, Y.T., Kebede, S.A. and Gashawbeza, G.T. 2012. Extent and pattern of genetic diversity for morpho-agronomic traits in Ethiopian sesame landraces (Sesamum indicum L.). Asian Journal of Agricultural Research 6:118-128.

Habtamu Seboka and Million Fikreselassie. 2013. Multivariate analysis of some Ethiopian field pea (Pisum sativum L.) genotypes. International Journal of Genetics and Molecular Biology 5:78-87.

Hammer, Ø., Harper, D. A. and Ryan, P.D. 2001. PAST: Paleontological statistics software package for education and data analysis. Palaeontologia Electronica 4:9.

Ibrahim, A.F., El-Kadi, D.A., Ahmed, A.K. and Shrief, S.A. 1983. Interrelationships and path-coefficient analysis for some characters in sesame (Sesamum indicum L.). Zeitschrift für Acker-und Pflanzenbau 152:454-459.

Institute of Biodiversity Conservation (IBC). 2012. Third country report on the state of plant genetic resources for food and agriculture. Addis Ababa, Ethiopia.

IPGRI and NBPGR (International Plant Genetic Resources Institute and National Bureau of Plant Genetic Resources). 2004. Descriptors for sesame (Sesamum spp.). P. Current Sociology. National Bureau of Plant Genetic Resources, New Delhi, India. pp. 342-344.

JMP®. 2002. User's Guide, Version 5. SAS Institute Inc., Cary, NC, USA.

Kim, D.H., Zur, G., Danin-Poleg, Y., Lee, S.W., Shim, K.B., Kang, C.W. and Kashi, Y. 2002. Genetic relationships of sesame germplasm collection as revealed by inter-simple sequence repeats. Plant Breeding 121:259262.

Laurentin, H.E. and Karlovsky, P. 2006. Genetic relationship and diversity in a sesame (Sesamum indicum L.) germplasm collection using amplified fragment length. BMC Genetics 10:1-10.

Million, F. 2012. Variability, heritability and association of some morpho-agronomic traits in field pea (Pisum sativum L.) genotypes. Pakistan Journal of Biological Sciences 15:358-366. 
Mkamilo, G.S. and Bedigian, D. 2007. In PROTA (Plant Resources of Tropical Africa/Ressources végétales de l'Afrique tropicale), Wageningen, Netherlands.

Mulugeta Atnaf Tiruneh, and Hussein Mohammed Ali 2013. Estimation of better parent and economic heterosis for yield and associated traits in common beans. Journal of Applied Biosciences 71:5706-5714.

Narayanan, A. and Reddy, K.B. 1982. Growth, development and yield of sesame (Sesamum indicum L.) cultivars. Field Crops Research 5:217-224.

Nath, R., Chakraborty, P. K. and Chakraborty, A. 2001. Effect of climatic variation on yield of sesame (Sesamum indicum L.) at different dates of sowing. Journal of Agronomy and Crop Science 186:97-102.

Osman, H.E. 1989. Heterosis and path coefficient analysis in sesame (Sesamum indicum L.). Acta Agronomica Hungarica 38:105-112.

Park, Y.C.J., Ra, C.L.W. and Lee, J.C.J. 2011. Evaluation of the genetic diversity and population structure of sesame (Sesamum indicum L.) using microsatellite markers. Genes \& Genomics 33:187-195.

Rabbani, M.A., Masood, M. and Shinwari, Z.K. 2010. Genetic analysis of basmati and non-basmati Pakistani rice (Oryza sativa L.) cultivars using microsatellite markers.

Saha, S., Begum, T. and Dasgupta, T. 2012. Analysis of genotypic diversity in sesame based on morphological and agronomic traits. Czech Genetics and Plant Breeding Journal 45:72-78.

SAS. 2002. System Analysis Software. Version 9.1.2. SAS Institute INC. Cary, North Carolina, USA.

Singh, R.K. and Chaudhary, B. 1985. Biometrical methods in quantitative genetic analysis. Kalyani Publishers, New Delhi, India.

Suddihiyam, P., Steer, B.T. and Turner, D.W. 1992. The flowering of sesame (Sesamum indicum $\mathrm{L}$.) in response to temperature and photoperiod. Australian Journal of Agricultural Research 43:1101-1116.

Uzun, B. and Çaðirgan, M.Ý. 2006. Comparison of determinate and indeterminate lines of sesame for agronomic traits. Field Crops Research 96:13-18.

Uzun*, B., Onur Özba ${ }^{\circ}$, M., Çanci, H., and Ýlhan Çaðirgan, M. 2004. Heterosis for agronomic traits in sesame hybrids of cultivars $\times$ closed capsule mutants. Acta Agriculturae Scandinavica, Section B-Soil \& Plant Science 54:108-112.

Uzun, B., Lee, D., Donini, P. and Çaçirgan, M.I. 2003. Identification of a molecular marker linked to the closed capsule mutant trait in sesame using AFLP. Plant Breeding 122:95-97.

Wei, X., Wang, L., Zhang, Y., Qi, X., Wang, X., Ding, X., Zhang, J. \& Zhang, X. 2014. Development of simple sequence repeat (SSR) markers of sesame (Sesamum indicum) from a genome survey. Molecules 19:5150-5162.

Weiss, E.A. 1983. Sesame. Oil seed crops. Longman, London. pp. 282-340.

Yadav, A.K., Thakral, S.K., Hari, S., Phool, S. and Tadav, T. P. 1988. Effect of morphophysiological attributes on PAR absorption and seed yield in sesame (Sesamum indicum L.). Journal of Oilseeds Research 5:155158.

Yebiyo Woldemariam. 1985. Sesame adaptation test in different agro ecological zones of Ethiopia. In: Abbas Omran (ed.) Oil crops/ : Sesame and Safflower. Proceedings of the Second Oil Crops Network Workshop held in Hyderabad,India. IDRC, Canada India. pp. 162-167.

Zohary, D., Hopf, M. and Weiss, E. 2012. Domestication of Plants in the Old World: The origin and spread of domesticated plants in Southwest Asia, Europe, and the Mediterranean Basin. P. Oxford. 